University of Nebraska - Lincoln

DigitalCommons@University of Nebraska - Lincoln

\title{
Analysis of off-grid hybrid wind turbine/solar PV water pumping systems
}

Brian D. Vick

USDA-ARS, brian.vick@ars.usda.gov

Byron A. Neal

USDA-ARS

Follow this and additional works at: https://digitalcommons.unl.edu/usdaarsfacpub

Part of the Agricultural Science Commons

Vick, Brian D. and Neal, Byron A., "Analysis of off-grid hybrid wind turbine/solar PV water pumping systems" (2012). Publications from USDA-ARS / UNL Faculty. 881.

https://digitalcommons.unl.edu/usdaarsfacpub/881

This Article is brought to you for free and open access by the U.S. Department of Agriculture: Agricultural Research Service, Lincoln, Nebraska at DigitalCommons@University of Nebraska - Lincoln. It has been accepted for inclusion in Publications from USDA-ARS / UNL Faculty by an authorized administrator of DigitalCommons@University of Nebraska - Lincoln. 


\title{
Analysis of off-grid hybrid wind turbine/solar PV water pumping systems
}

\author{
Brian D. Vick*, Byron A. Neal \\ USDA ${ }^{1}$, Agricultural Research Service, P.O. Drawer 10, Bushland, TX 79012, United States
}

Received 30 September 2011; received in revised form 6 January 2012; accepted 16 January 2012

Available online 9 February 2012

Communicated by: Associate Editor Mukund Patel

\begin{abstract}
While many remote water pumping systems exist (e.g. mechanical windmills, solar photovoltaic, wind-electric, diesel powered), few combine both the wind and solar energy resources to possibly improve the reliability and the performance of the system. In this paper, off-grid wind turbine (WT) and solar photovoltaic (PV) array water pumping systems were analyzed individually and combined as a hybrid system. The objectives were to determine: (1) advantages or disadvantages of using a hybrid system over using a WT or a solar PV array alone; (2) if the WT or solar PV array interfered with the output of the other; and (3) which hybrid system was the most efficient for the location. The WT used in the analysis was rated at $900 \mathrm{~W}$ alternating current (AC). There were three different solar PV arrays analyzed, and they were rated at 320,480, and $640 \mathrm{~W}$ direct current (DC). A rectifier converted the 3-phase variable voltage AC output from the WT to DC before combining it with the solar PV array DC output. The combined renewable energies powered a single helical pump. The independent variable used in the hybrid WT/PV array analysis was in units of $\mathrm{W} / \mathrm{m}^{2}$. The peak pump efficiency of the hybrid systems at Bushland, TX occurred for the $900 \mathrm{~W}$ WT combined with the $640 \mathrm{~W}$ PV array. The peak pump efficiencies at a $75 \mathrm{~m}$ pumping depth of the hybrid systems were: $47 \%$ (WT/320 W PV array), 51\% (WT/480 W PV array), and 55\% (WT/640 W PV array). Interference occurred between the WT and the different PV arrays (likely due to voltage mismatch between WT and PV array), but the least interference occurred for the WT/320 W PV array. This hybrid system pumped $28 \%$ more water during the greatest water demand month than the WT and PV systems would have pumped individually. An additional controller with a buck/boost converter is discussed at end of paper for improvement of the hybrid WT/PV array water pumping system.
\end{abstract}

Published by Elsevier Ltd.

Keywords: Wind; Solar; Hybrid; Water pumping; PV; Wind turbine

\section{Introduction}

Water has been pumped using wind energy for centuries (Nelson et al., 2004; Nelson, 2009), and by solar energy for the past half century (Foster, 2009; Odeh et al., 2006). Remote locations have primarily used mechanical windmills for pumping water; however, many farmers and ranchers have switched to solar PV water pumping systems. For

\footnotetext{
* Corresponding author. Tel.: +1 806356 5752; fax: +1 8063565750.

E-mail address: brian.vick@ars.usda.gov (B.D. Vick).

${ }^{1}$ USDA is an equal opportunity provider and employer.
}

remote water pumping systems greater than $10 \mathrm{~kW}$, diesel is the predominant energy source for water pumping systems in Egypt (Kamel and Dahl, 2005). Small wind turbines $^{2}$ currently are not used for many remote water pumping systems compared with mechanical windmills and solar PV arrays. Potential improvement in reliability (e.g. not dependent on wind or solar resources alone) and increased daily water volume could be realized by utilizing

\footnotetext{
${ }^{2}$ Small WT's are defined by the American Wind Energy Association (AWEA) as having a blade rotor swept area less than $200 \mathrm{~m}^{2}$ or approximately 50 to $60 \mathrm{~kW}$ power rating.
} 
hybrid WT/PV array systems which would also increase the number of small WT's used for water pumping.

The USDA-Agricultural Research Service Conservation and Production Research Laboratory (CPRL), Bushland, Texas, in collaboration with the West Texas A\&M University - Alternative Energy Institute, Canyon, Texas, has conducted extensive research on renewable energy powered remote water pumping systems. The main criticism voiced to CPRL by farmers and ranchers in the Texas Panhandle concerning mechanical windmills is the high maintenance required for the piston pump (specifically the degradation of leather cups or poly vinyl cups which are used to seal the piston pump during the pumping action). This feedback led the CPRL to focus on the development of more reliable systems (e.g. less maintenance) using submersible turbine pumps for wells. These pumps were produced in great quantities (e.g. low cost) for rural utility connected systems and operate on single or 3-phase AC power. Small WT's with permanent magnet alternators output 3-phase variable voltage/frequency AC electricity. Therefore, WT's were a natural choice for powering the submersible turbine pumps. While small WT's/centrifugal pumps outperformed mechanical windmills/piston pumps at pumping depths of 20-30 m (Vick and Clark, 1997), the lower cut-in wind speed of mechanical windmills/piston pumps resulted in appreciably better performance at a $75 \mathrm{~m}$ pumping depth during the summer than the wind-electric centrifugal pumps (Vick et al., 1999). However, connecting a WT to a DC pump motor (via a rectifier that converted AC to DC) to power a helical pump (a positive displacement pump) resulted in pumping performance equivalent to or better than that of a mechanical windmill/piston pump during the summer months at a $75 \mathrm{~m}$ pumping depth (Vick and Clark, 2005). Modifying the controller of the WT powered helical pump system to include a controller load (could be used to heat water in the stock tank during the winter) also resulted in increased daily water pumped (Neal and Clark, 2007).

One major advantage of PV powered water pumping systems versus wind powered water pumping systems is that typically the solar resource matches the agricultural water needs, such as livestock watering or crop/vegetable irrigation, better than wind resource. This is because the solar resource is usually greatest during the summer when the water demand is also the greatest; whereas, the wind resource in the Southern Great Plains is typically the lowest in the summer. Solar PV powered diaphragm pump water pumping systems (a diaphragm pump is a positive displacement pump), are most often low volume ( $\sim 800 \mathrm{~L} /$ day for a $70 \mathrm{~m}$ maximum pumping depth) or are limited in pumping depth (30 $\mathrm{m}$ for a $\sim 5000 \mathrm{~L} /$ day water volume) (Vick and Clark, 2009). Since the pumping depth at the CPRL is $75 \mathrm{~m}$, diaphragm pumps should not be used in the CPRL wells. There are also PV powered helical pump systems which are capable of higher daily water volumes (up to $\sim 8000 \mathrm{~L} /$ day at $75 \mathrm{~m}$ pumping depth) and deeper pumping depths $(\sim 3000 \mathrm{~L} /$ day at a $150 \mathrm{~m}$ pumping depth $)$ that require higher rated power than the $\mathrm{PV}$ powered diaphragm pump systems (Vick and Clark, 2009, 2011). The PV array rated power for typical diaphragm pump systems range from 75 to $150 \mathrm{~W}$; whereas, the $\mathrm{PV}$ rated power for helical pump systems range from 200 to $1000 \mathrm{~W}$. Reliability of solar PV powered helical pump systems is better than that of solar PV powered diaphragm pump systems for pumping depths greater than $30 \mathrm{~m}$ (Vick and Clark, 2011). A comparison was made between WT powered and solar PV powered helical pumps for livestock watering. The solar powered helical pump systems were found to be a better match to the livestock water requirement in the Southern Great Plains (Clark and Vick, 2008).

A number of locations have studied hybrid WT/PV array systems. Hybrid WT/PV array systems with battery backup have been shown to be reliable (e.g. as compared to using WT or solar PV alone) in certain locations (Zhou and Yang, 2008). At the CPRL we have a good wind/solar resource location since we are classified as a Class 4 wind site (WTAMU-AEI, 2011), and our annual daily average solar insolation is $5.8 \mathrm{~kW} \mathrm{~h} \mathrm{~m} \mathrm{~d}^{-1}$ for a PV module at latitude tilt (Marion and Wilcox, 1994). Our renewable energy group developed a hybrid wind/solar/battery system ${ }^{3}$ composed of a $300 \mathrm{~W}$ WT, $100 \mathrm{~W}$ PV array, and two $12 \mathrm{~V}$ 100 A-h deep cycle batteries to supply power to a remote data acquisition system with an electrical loading of $2 \mathrm{~A} / \mathrm{h}$ (Vick et al., 1999). The final WT/PV/battery system has proven to be very reliable, and the only maintenance item has been to replace the batteries every 2 years. There are several models for the designing of hybrid wind/solar systems for on-grid or off-grid applications. Zhou et al. (2010) reviewed the more common optimizing models that can be used for hybrid wind-solar systems. Two of the models mentioned by Zhou were the Hybrid Optimization Model for Electric Renewables (HOMER, Lilienthal, 2005) and Hybrid2 (Baring-Gould, 1998) which are available in the public domain. Another model mentioned in Zhou et al. (2010) is the Hybrid Solar-Wind System Optimization Sizing (HSWSO, Yang et al., 2007). The HSWSO model is specifically for a hybrid solar-wind power system employing a battery bank. Renewable energy powered water pumping systems seldom use batteries for storage of energy because it is more cost effective to store the water. Also, most, if not all, of these models require electrical loading data to be input, but in water pumping for livestock most farmers/ranchers/agricultural extension personnel only know the daily water requirement for the livestock.

The objectives of our hybrid off-grid WT/PV array research were to determine:

1. advantages and disadvantages of using hybrid WT/PV system over using WT or solar PV array alone;

2. if the WT or solar PV portion of hybrid system interfered with output of the other components; and 3. which hybrid system was most efficient at our location.

\footnotetext{
${ }^{3}$ Hybrid systems developed by trial and error rather than a model.
} 
The optimum PV array size for a WT will be determined by which configuration has the highest pump efficiency.

\section{Materials and methods}

Renewable energy powered water pumping experiments were conducted at the USDA-ARS CPRL in Bushland, Texas. A $900 \mathrm{~W}$ WT and three different PV arrays (320, 480 , and $640 \mathrm{~W}$ ) with $160 \mathrm{~W} / 24 \mathrm{~V}$ multi-crystalline modules were installed and operated to determine individual water pumping performance. The WT and solar PV arrays were also combined into hybrid WT/PV array systems to determine the hybrid water pumping performance. The pump selected for this study was a Grundfos ${ }^{4}$ (Olathe, Kansas) 11SQF-2 helical pump. This pump was selected because its DC power requirement could exceed $1000 \mathrm{~W}$, and the power generation of the $900 \mathrm{~W}$ WT and $640 \mathrm{~W}$ $\mathrm{PV}$ array were each less than $1000 \mathrm{~W}$. The flow rate was approximately $42 \mathrm{~L} / \mathrm{min}$ at a $75 \mathrm{~m}$ pumping depth for a $1000 \mathrm{~W}$ DC input. Pumping depths from 30 to $120 \mathrm{~m}$ were simulated using a back pressure valve; however, only the $75 \mathrm{~m}$ pumping depth data are presented. This pump was also selected because with a Grundfos IO102 wind generator interface box, the variable voltage/frequency 3-phase AC electricity from the WT could be rectified to DC and added to the DC electricity output from the PV array.

The following data were collected from October 6, 2010 until August 31, 2011 on off-grid WT, PV array, and hybrid WT/PV arrays:

1. Day of year

2. Time of day $-\mathrm{h} / \mathrm{min}$ (Central Standard Time)

3. Air temperature $-{ }^{\circ} \mathrm{C}$

4. Solar radiation $-\mathrm{W} / \mathrm{m}^{2}$

5. $\mathrm{PV}$ array $\mathrm{DC}$ voltage $-\mathrm{V}$

6. PV array DC current $-\mathrm{A}$

7. $\mathrm{PV}$ module temperature $-{ }^{\circ} \mathrm{C}$

8. Wind speed at WT hub height $-\mathrm{m} / \mathrm{s}$

9. WT 3-phase AC voltage - V

10. WT AC power - W

11. Input DC voltage to pump motor $-\mathrm{V}$

12. Input DC current to pump motor $-\mathrm{A}$

13. Water pressure $-\mathrm{kP}$

14. Water flow rate $-\mathrm{L} / \mathrm{min}$

Most data were measured at $1 \mathrm{~Hz}$ with the exceptions being wind speed and water flow rate which were measured at $0.1 \mathrm{~Hz}$ (e.g. $10 \mathrm{~s})$. All the data were averaged for 1-min time periods and stored on an electronic module connected to the data logger.

\footnotetext{
${ }^{4}$ The mention of trade, firm, or corporation names of commercial products in this publication is for the information and convenience of the reader. Such use does not constitute an official endorsement or approval by the United States Department of Agriculture or the Agricultural Research Service of any product or service to the exclusion of others that may be suitable.
}

The air temperature and PV module temperatures were measured with copper-constantan thermocouples (the air temperature probe was enclosed in a radiation shield and the PV module probe was mounted to the back of one of the PV modules). The solar irradiance was measured with a Campbell Scientific Instruments (Provo, Utah) LI-COR LI-200 pyranometer which was mounted in the plane of the PV array. The wind speed was measured with a Met One (Grants Pass, Oregon) model 014 (regular) anemometer from September 2010 to December, 2010 and a Met One model 014 (mini) from December 2010 to the end of data collection. The DC voltage and DC current of the PV array were measured with CR Magnetics (St. Louis, Missouri) models CR5310-200 (e.g. $200 \mathrm{~V}$ full scale) and CR5210-10 (e.g. $10 \mathrm{~A}$ full scale) transducers, respectively. The DC voltage and DC current for the pump motor were measured with CR Magnetics Models CR5310-500 (e.g. $500 \mathrm{~V}$ full scale) and CR5310-50 (e.g. 50 A full scale) transducers, respectively. The $24 \mathrm{~V}$ DC power supply for the CR Magnetics transducers was a CR Magnetics Model CRPS24VDC-120. This power supply was used because it is important that a precise/accurate $24 \mathrm{~V} \mathrm{DC}$ signal is input to the CR Magnetics voltage and current transducers to obtain $+/-0.5 \%$ accuracy. The AC voltage across two phases and the 3-phase AC power output from the WT were measured with an Ohio Semitronics (Hilliard, Ohio) Model VT8-008B and a Flex-Core (Hilliard, Ohio) Model $\mathrm{P}-142 \times 5$ (with 20 wire turns through current transducers to obtain a maximum output of $1 \mathrm{~kW}$ ), respectively. Water pressure was measured with a Honeywell (Morristown, New Jersey) Model EA300PS100 transducer. Water flow rate was measured with a Hersey (Cleveland, North Carolina) MVR 30/R-38 transducer. Voltage and current transducer readings were checked for accuracy with a calibrated Fluke (Everett, Washington) Model $87 \mathrm{~V}$ in September 2010.

The flow rate of the helical pump was checked at the same time that the pump curves were generated using the utility grid as a power source. Pump curve data were collected on 9/21/2010, 12/2/2010, and 6/3/2011. In May, 2011 there was a failure of the rectifier in the Grundfos IO102 wind generator interface box, and so a pump curve was collected on 6/3/2011. Little degradation in the pump performance was evident between 9/21/2010 and 12/2/ 2010 , but some degradation in the pump was evident between 12/2/2010 and 6/3/2011 (Table 1). The pump performance degradation was only $5.4 \%$ at the $75 \mathrm{~m}$ pumping depth, so data collection at this pumping depth continued on 6/9/2011 after installing a new IO102 box.

The pump efficiency was determined by the following equation which can be derived from Newton's second law of motion:

$$
\begin{aligned}
P_{\text {eff }}= & P_{w} / P_{\text {input }} * 100 \% \\
= & H * Q *(\min / 60 \mathrm{~s}) *\left(\mathrm{~m}^{3} / 1000 \mathrm{~L}\right) * g \\
& * \rho_{H 20} / P_{\text {input }}
\end{aligned}
$$


Table 1

Pump curves of Grundfos 11SQF-2 pump using utility power.

\begin{tabular}{lllll}
\hline Pressure $(\mathrm{kP})$ & Head $(\mathrm{m})$ & $9 / 21 / 2010$ & $12 / 2 / 2010$ & $6 / 3 / 2011$ \\
& & Flow rate $(\mathrm{L} / \mathrm{min})$ & Flow rate $(\mathrm{L} / \mathrm{min})$ & Flow rate $(\mathrm{L} / \mathrm{min})$ \\
\hline 276 & 30 & 48.4 & 47.7 & 47.4 \\
483 & 50 & 47.1 & 46.6 & 45.1 \\
724 & 75 & 45.6 & 45.0 & 42.1 \\
965 & 100 & 32.4 & 32.2 & 27.3 \\
1172 & 120 & 22.1 & 22.1 & 16.8 \\
\hline
\end{tabular}

where $P_{\text {eff }}$ is the pump efficiency (\%), $P_{w}$ is power to pump water at a specific head $(\mathrm{W}), P_{\text {input }}$ is DC Power input to pump (W), $H$ is static pumping depth + pressure to overcome back pressure valve ${ }^{5}(\mathrm{~m}), Q$ is average volumetric flow rate $(\mathrm{L} / \mathrm{min}), g$ is gravity $\left(9.8 \mathrm{~m} / \mathrm{s}^{2}\right)$, and $\rho_{H 20}$ is the density of water $\left(1000 \mathrm{~kg} / \mathrm{m}^{3}\right)$.

During the analysis of the hybrid off-grid WT/PV array data, it was decided that the WT, PV, and WT/PV systems needed to be analyzed with the same independent variable. The statistical method we have used for analyzing WT and solar PV data has been the Method of Bins (Akins, 1978). The independent variable we normally used for binning WT systems was wind speed $(\mathrm{m} / \mathrm{s})$ and the independent variable used for binning PV systems was solar irradiation $\left(\mathrm{W} / \mathrm{m}^{2}\right)$. Therefore, the independent variable selected for binning the WT data was wind power density $\left(\mathrm{W} / \mathrm{m}^{2}\right)$ and this independent variable could be obtained using wind speed, air density $\left(\rho_{\text {air }}\right)$, and the following equation (Gipe, 2004):

Power $_{\text {wind }} / A_{\text {ref }}=0.5 \times \rho_{\text {air }} \times V^{3}$

where Power ${ }_{\text {wind }}$ is the Power in the wind (W), $A_{\text {ref }}$ the reference area of WT which is normally the swept area of the rotor blade $\left(\mathrm{m}^{2}\right), \rho_{\text {air }}$ the air density $\left(\mathrm{kg} / \mathrm{m}^{3}\right)$, and $V$ is the average wind speed during certain time interval $(\mathrm{m} / \mathrm{s})$.

Air density is a function of air temperature and barometric pressure, and can be calculated using the ideal gas law equation. No barometric pressure was collected on this data acquisition system, but barometric pressure was collected on another data acquisition system during the same time period at CPRL. Using wind speed, air temperature, barometric pressure, the ideal gas law equation, and Eq. (2), wind power density could be calculated which was in the same units as the solar resource data. For analyzing the hybrid WT/PV systems the wind power density and the solar irradiance could then be added. Another important point about collecting wind and solar resource data for hybrid off-grid systems is that the data must be collected at the same time because the time when wind and solar energy contributions occur has an effect on the operation of off-grid hybrid wind/solar systems.

To determine whether a specific renewable energy system will meet the water requirement, the daily water

\footnotetext{
${ }^{5}$ The head loss due to pipe friction was neglected due to short pipe runs and low flow rates.
}

volume pumped and the daily water volume required are predicted for each month of the year. The predicted daily water volume pumped for each month was obtained by: (1) multiplying the average volumetric flow rate (e.g. L/ $\mathrm{min}$ ) of the WT, PV, or WT/PV system for each $100 \mathrm{~W} /$ $\mathrm{m}^{2}$ bin by the amount of time (e.g. min) in that bin for each month, (2) sum the volumes (L) in each bin to get the total volume for the month, and (3) divide that total volume by the number of days in the month. In this paper, when a "/" is used as in WT/PV, that indicates a hybrid, and if a "+" is used, as in WT + PV, that implies the water is pumped separately by the WT and PV systems and the daily water volumes are simply added. To determine a typical year for a hybrid system, the average daily wind and solar energy should be determined for several years, and the year chosen should be close to the average. The average measured daily wind energy and solar energy at CPRL (Bushland, TX) were collected on another data acquisition system and are displayed in Fig. 1. The global daily solar energy represents total solar radiation measured on a flat surface (e.g. zero degree incidence) with LI-COR (Lincoln, Nebraska) pyranometers. Wind energy is a function of wind speed, air temperature, and air pressure. The wind speed at a $10 \mathrm{~m}$ height was measured with Met One Model 014 anemometers. The air temperature was measured with a Campbell Scientific Instruments Model 107 thermistor. The barometric pressure was measured with a Yellow Springs Model 2014785 (Yellow Springs, Ohio) from 1983 to June 2008, and a Met One Model 092 from July 2008 to present. Both the solar and wind energy data were estimated from hourly data. The year 2006 was close to being an average wind energy year, and although the solar energy for 2006 was greater than average, the 2006 year appeared to be the best fairly recent year to select for an average wind and solar

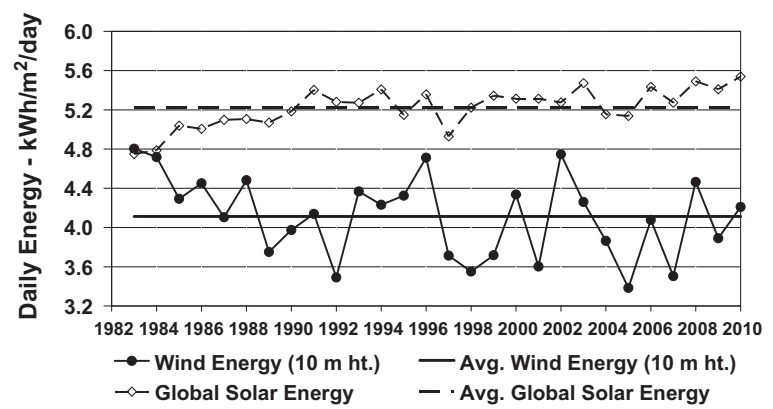

Fig. 1. Average daily wind and solar energy at Bushland, Texas from 1983 to 2010 (symbols are mean values). 
energy year. The wind speed data used during 2006 were from another CPRL data acquisition system where the data were measured with a Met One model 014 anemometer at a height of $18.5 \mathrm{~m}$ and recorded every minute. The solar irradiance data used during 2006 were measured with a LI-COR pyranometer from another CPRL data acquisition system which was in the plane of a fixed PV array and incidence was $25^{\circ}$ during spring/summer and $45^{\circ}$ during fall/winter and these data were recorded every minute. To determine how well the renewable energy system is meeting the monthly water demand, the monthly water demand also needs to be determined. Since the main purpose of remote water pumping systems at our location is watering cattle, the water demand estimated for 2006 was for watering range cattle. The amount of water needed by cattle can vary greatly depending on the size of the cattle, time of the year, and whether they are on a range or in a feedlot (Hicks et al., 1988).

\section{Results and discussion}

\subsection{Analysis of DC power output of wind turbine, $P V$ arrays, and hybrid wind turbine/PV array systems}

In Figs. 2 and 3 the DC power output is presented for the $900 \mathrm{~W}$ WT with wind speed and wind power density

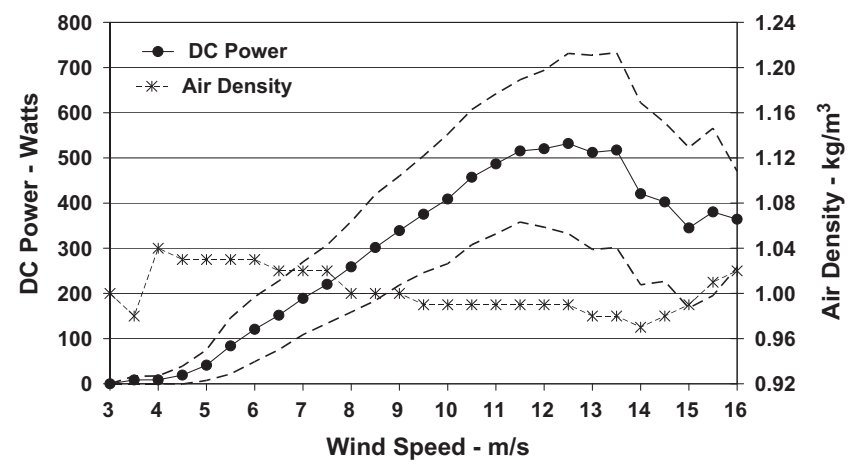

Fig. 2. Measured DC power output of $900 \mathrm{~W}$ WT and air density with wind speed as independent variable (symbols are mean values and dashed lines represent $+/-1$ standard deviation).

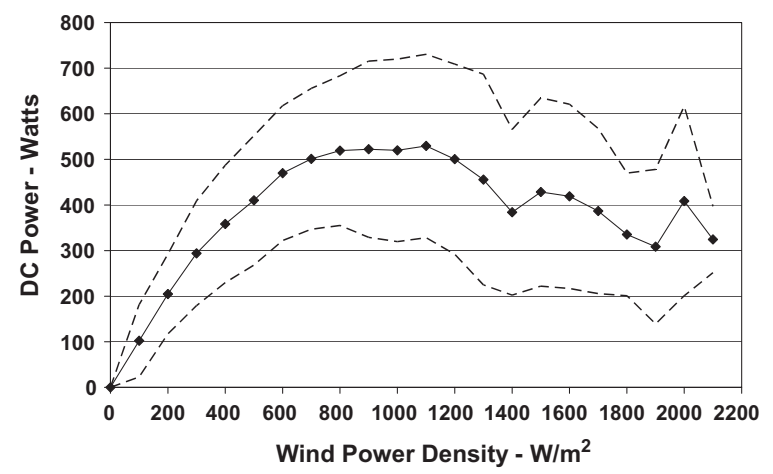

Fig. 3. Measured DC power output of $900 \mathrm{~W}$ WT with wind power density as independent variable (symbols are mean values and dashed lines represent $+/-1$ standard deviation). as the independent variables, respectively. The data were collected from 6/24/2011 until 7/3/2011. A DC power output of $100 \mathrm{~W}$ occurred at a wind speed of $5.5 \mathrm{~m} / \mathrm{s}$ or a wind power density of $100 \mathrm{~W} / \mathrm{m}^{2}$. A DC power output of $500 \mathrm{~W}$ was achieved at a wind speed of $11.5 \mathrm{~m} / \mathrm{s}$ or a wind power density of $700 \mathrm{~W} / \mathrm{m}^{2}$. The average peak measured power in both figures was approximately $520 \mathrm{~W}$. The variation in the data, whether the independent variable is wind speed or wind power density, was large $(+/-100$ to $200 \mathrm{~W})$. Although significant variation for WT power curves is common, the pump controller of the helical pump could be contributing to some of the data variation. At wind speeds above $13.5 \mathrm{~m} / \mathrm{s}$ the WT began furling (e.g. WT turning out of the wind due to center of the blade rotor axis being offset from the tower axis), and the power decreased for greater wind speeds. Furling is a characteristic of many small WT's for over-speed protection. A wind speed of $13.5 \mathrm{~m} / \mathrm{s}$ corresponds to a wind power density of approximately $1100 \mathrm{~W} / \mathrm{m}^{2}$, and a wind speed of $16 \mathrm{~m} / \mathrm{s}$ corresponds to a wind power density of approximately $2100 \mathrm{~W} / \mathrm{m}^{2}$. In terms of water pumping performance for small wind turbines at our location, wind speeds above $16 \mathrm{~m} / \mathrm{s}$ make little contribution to overall water pumped. Table 2 presents the wind speed distribution for Bushland, TX (18.5 m height) during 2006 based on 1-min data, and only $0.5 \%$ of data occurred above wind speed of $16 \mathrm{~m} / \mathrm{s}$.

Fig. 4 presents the measured DC power of the three different PV arrays tested. The data were collected for the 320,480 , and $640 \mathrm{~W}$ solar PV array systems during the following periods: $10 / 20 / 2010-10 / 28 / 2010,8 / 18 / 2011-8 / 28 /$ 2011, and 6/10/2011-6/22/2011, respectively. A DC power output of $100 \mathrm{~W}$ occurred at a solar irradiance of approximately $430 \mathrm{~W} / \mathrm{m}^{2}$ for the $320 \mathrm{~W}$ PV array while a $100 \mathrm{~W}$ power output was achieved at a solar irradiance of approximately $270 \mathrm{~W} / \mathrm{m}^{2}$ and $220 \mathrm{~W} / \mathrm{m}^{2}$ for the 480 and $640 \mathrm{~W}$ PV arrays, respectively. Solar PV modules are rated at a solar irradiance of $1000 \mathrm{~W} / \mathrm{m}^{2}$ and a PV module temperature of $25^{\circ} \mathrm{C}$. At a $1000 \mathrm{~W} / \mathrm{m}^{2}$ solar irradiance, the solar PV arrays of 320,480 , and $640 \mathrm{~W}$ achieved DC power outputs of approximately 253,378 , and $502 \mathrm{~W}$, respectively. These PV modules are multi-crystalline which typically lose $0.7 \%$ in performance each year (Osterwald et al. 2002), and $0.5 \%$ for each ${ }^{\circ} \mathrm{C}$ above $25{ }^{\circ} \mathrm{C}$ (BP Solar, 2003). Since these PV modules are 7 years old and the PV module temperatures were 42,57 , and $51^{\circ} \mathrm{C}$ for the 320,480 , and $640 \mathrm{~W}$ PV arrays, if the PV modules were new and the PV module temperature was $25^{\circ} \mathrm{C}$, the DC power output at a solar irradiance of $1000 \mathrm{~W} / \mathrm{m}^{2}$ was estimated to be 287,457 , and $602 \mathrm{~W}$, respectively. Therefore, these PV modules were about $5-10 \%$ below their ratings. Another curve is presented in Fig. 4 that was collected in the winter $(1 / 8 /$ 2011-1/13/2011) for the $640 \mathrm{~W}$ PV array. At a solar irradiance of $1000 \mathrm{~W} / \mathrm{m}^{2}$, a PV module temperature of $21^{\circ} \mathrm{C}$, and assuming a power degradation of $0.5 \% /{ }^{\circ} \mathrm{C}$, this $640 \mathrm{~W}$ PV array should have been $15 \%$ greater or $577 \mathrm{~W}$. The actual average measured DC power output was $542 \mathrm{~W}$ which implies that the power degradation with PV 
Table 2

Hourly wind speed distribution at Bushland, Texas (18.5 m height) for 2006.

\begin{tabular}{|c|c|c|c|c|c|c|c|c|c|c|c|c|c|c|c|c|c|c|c|c|}
\hline $\mathrm{m} / \mathrm{s}$ & 0.5 & 1.0 & 1.5 & 2.0 & 2.5 & 3.0 & 3.5 & 4.0 & 4.5 & 5.0 & 5.5 & 6.0 & 6.5 & 7.0 & 7.5 & 8.0 & 8.5 & 9.0 & 9.5 & 10.0 \\
\hline h & 81 & 51 & 152 & 262 & 372 & 428 & 502 & 551 & 600 & 640 & 632 & 635 & 575 & 513 & 425 & 376 & 321 & 290 & 245 & 203 \\
\hline $\mathrm{m} / \mathrm{s}$ & 10.5 & 11.0 & 11.5 & 12.0 & 12.5 & 13.0 & 13.5 & 14.0 & 14.5 & 15.0 & 15.5 & 16.0 & 16.5 & 17.0 & 17.5 & 18.0 & 18.5 & 19.0 & 19.5 & $>20$ \\
\hline $\mathrm{h}$ & 180 & 151 & 128 & 104 & 81 & 63 & 46 & 36 & 26 & 20 & 16 & 12 & 10 & 8 & 6 & 5 & 4 & 3 & 2 & 6 \\
\hline
\end{tabular}

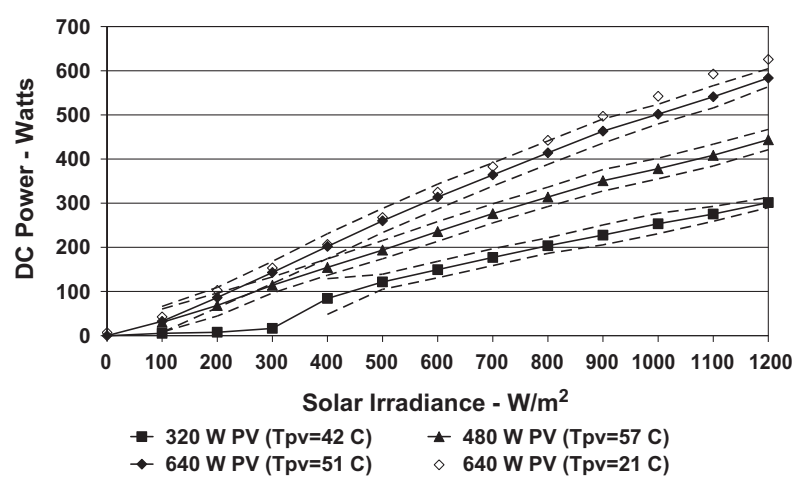

Fig. 4. Measured DC power output of 320,480 , and $640 \mathrm{~W}$ PV arrays with solar irradiance as independent variable (symbols are mean values and dashed lines represent $+/-1$ standard deviation).

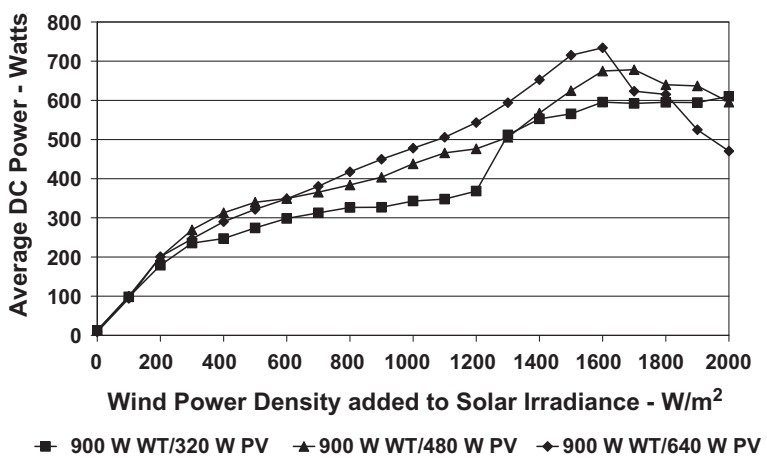

Fig. 5. Average measured DC power output of three hybrid WT/PV array water pumping systems (symbols are mean values).

module temperature was only about $0.25 \% /{ }^{\circ} \mathrm{C}$. Of course other conditions can affect DC power output such as soiling of PV modules. Comparing Fig. 4 to Fig. 3, it is obvious that the variation in DC power output is much less with the solar PV array than that for the WT. The standard deviation of the DC power output of the solar PV arrays was $+/-10$ to $20 \mathrm{~W}$ which is an order of magnitude less than the standard deviation of the WT.

Fig. 5 presents the average DC power output of all three hybrid WT/PV array systems tested (900 W WT with $320 \mathrm{~W}$ PV array, $480 \mathrm{~W}$ PV array, and $640 \mathrm{~W}$ PV array). The average standard deviations (not shown) for the $\mathrm{WT} / 320 \mathrm{~W} \mathrm{PV}$ array, WT/480 W PV array, and WT/ $640 \mathrm{~W}$ PV array were $+/-161 \mathrm{~W},+/-215 \mathrm{~W}$, and +/ $-250 \mathrm{~W}$, respectively. The data were binned with the sum of the wind power density and the solar irradiance. Up to $200 \mathrm{~W} / \mathrm{m}^{2}$, all three hybrids had approximately the same DC power output, probably because the WT dominated the DC power output. From 300 to $500 \mathrm{~W} / \mathrm{m}^{2}$ the DC power output of the WT/480 W PV hybrid system was slightly higher than that of the WT/640 W PV hybrid system. From 700 to $1600 \mathrm{~W} / \mathrm{m}^{2}$ the DC power output of the WT/640 W PV hybrid system was $10-80 \mathrm{~W}$ greater than that of the WT/480 W PV hybrid system. The average peak DC power outputs of the WT/320 W PV, WT/480 W $\mathrm{PV}$, and WT/640 W PV hybrid systems were 611,678 , and $734 \mathrm{~W}$, respectively. The $\mathrm{WT} / 320 \mathrm{~W}$ PV hybrid system reached an average DC power plateau of approximately $600 \mathrm{~W}$ at $1600 \mathrm{~W} / \mathrm{m}^{2}$. The WT/480 W PV hybrid system reached an average peak DC power of $678 \mathrm{~W}$ at $1600 \mathrm{~W} /$ $\mathrm{m}^{2}$ and gradually declined. The WT/640 W PV hybrid system reached an average peak DC power of $734 \mathrm{~W}$ at $1600 \mathrm{~W} / \mathrm{m}^{2}$ and declined more rapidly in DC power than the other two hybrids. For the WT/320 W PV hybrid system, there is a sudden increase in average DC power between 1200 and $1300 \mathrm{~W} / \mathrm{m}^{2}$. This steep increase in average DC power may be due to the WT dominating the $320 \mathrm{~W}$ PV array in DC output, whereas the $320 \mathrm{~W}$ PV array began to make more contribution when the WT began furling, which caused the DC power to remain constant at the highest level (e.g. this is a potential beneficial aspect of using a hybrid versus using just a WT or a solar PV array).

\subsection{Analysis of water pumping performance of wind turbine, $P V$ arrays, and hybrid wind turbine/PV arrays}

In Fig. 6 the water flow rates produced by the $900 \mathrm{~W}$ WT, $320 \mathrm{~W}$ PV array, $480 \mathrm{~W}$ PV array, and $640 \mathrm{~W}$ PV array are compared. The DC power curves in Figs. 3 and 4 look very similar to the flow rate curves in Fig. 6. The relative size of the standard deviation of the water flow rates and the DC power were approximately the same as well. The water flow rate produced by the $900 \mathrm{~W}$ WT was greatest for smaller wind power densities (i.e. $<1000 \mathrm{~W} / \mathrm{m}^{2}$ ) reaching an average peak water flow rate of $20 \mathrm{~L} / \mathrm{min}$ at $800 \mathrm{~W} / \mathrm{m}^{2}$. The $900 \mathrm{~W}$ WT began pumping water at $100 \mathrm{~W} / \mathrm{m}^{2}$ whereas the 480 and $640 \mathrm{~W}$ PV arrays began pumping water at $200 \mathrm{~W} / \mathrm{m}^{2}$, and the $320 \mathrm{~W} \mathrm{PV}$ array did not begin pumping water until $400 \mathrm{~W} / \mathrm{m}^{2}$. The $640 \mathrm{~W}$ PV array had a similar water flow rate as that of the $480 \mathrm{~W}$ PV array until $400 \mathrm{~W} / \mathrm{m}^{2}$ when the water flow rate curves began to diverge. The water flow rate of the $900 \mathrm{~W}$ WT began decreasing like that of the DC power curve (Fig. 3) at $1100 \mathrm{~W} / \mathrm{m}^{2}$. The pump efficiencies of the WT and the three PV arrays are compared in Fig. 7. The pump efficiency of the $320 \mathrm{~W}$ PV array was appreciably less 


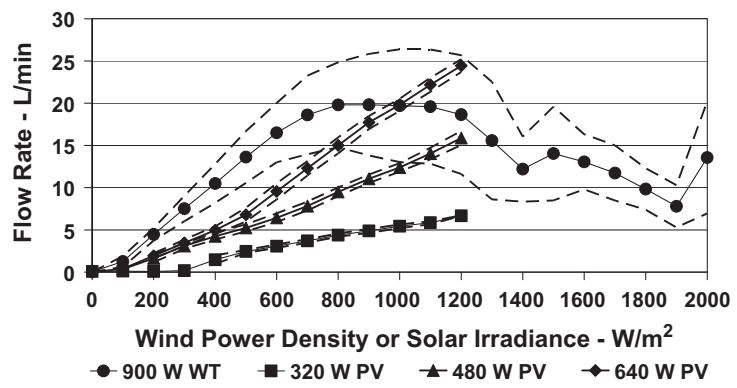

Fig. 6. Measured water flow rates of a Grundfos 11SQF-2 pump (75 m head) powered by a $900 \mathrm{~W}$ WT and three solar PV arrays $(320,480$, and $640 \mathrm{~W})$. Symbols are mean values and dashed lines represent $+/-1$ standard deviation.

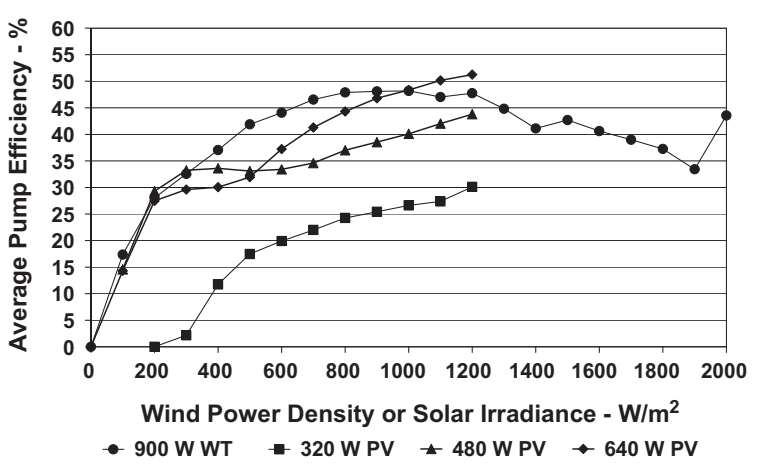

Fig. 7. Average measured pump efficiency of a Grundfos $11 \mathrm{SQF}-2$ pump (75 m head) powered by a $900 \mathrm{~W}$ WT and three solar PV arrays (320, 480, and $640 \mathrm{~W})$.

than that of the other two PV arrays (e.g. 480 and $640 \mathrm{~W}$ ) and the $900 \mathrm{~W}$ WT. The pump efficiency of the $900 \mathrm{~W}$ WT and the 480 and $640 \mathrm{~W}$ PV arrays were approximately the same up to $200 \mathrm{~W} / \mathrm{m}^{2}$, but from 300 to $1000 \mathrm{~W} / \mathrm{m}^{2}$ the WT was more efficient. The average pump efficiency of the $480 \mathrm{~W}$ PV array was greater than the $640 \mathrm{~W}$ PV array from 300 to $400 \mathrm{~W} / \mathrm{m}^{2}$, but from 600 to $1200 \mathrm{~W} / \mathrm{m}^{2}$ the average pump efficiency of the $640 \mathrm{~W}$ PV array was always greater than that of the $480 \mathrm{~W}$ PV array. The peak pump efficiencies of the $900 \mathrm{~W}$ WT, $320 \mathrm{~W}$ PV array, $480 \mathrm{~W}$ PV array, and the $640 \mathrm{~W} \mathrm{PV}$ array were $48 \%, 30 \%, 44 \%$, and $51 \%$, respectively.

In Fig. 8 the predicted daily water pumped by the $900 \mathrm{~W}$ WT (18.5 and $10 \mathrm{~m}$ hub heights), $320 \mathrm{~W}$ PV array, $480 \mathrm{~W}$ $\mathrm{PV}$ array, and $640 \mathrm{~W} \mathrm{PV}$ array were compared for the year 2006 at the Bushland, TX location. The predicted daily water volume needed by a $273 \mathrm{~kg}(600 \mathrm{lb})$ beef cow varied approximately linearly from $20 \mathrm{~L} /$ day in January to $50 \mathrm{~L} /$ day in August and then back down to $20 \mathrm{~L} /$ day in December. The $900 \mathrm{~W}$ WT pumped the least amount of water in the late summer when the amount of water needed by the cattle was greatest. The amount of water pumped by the PV arrays was fairly constant during the year. This was partly due to our procedure of changing the PV array incidence at the spring and fall equinoxes, so that the PV array incidence was set at $25^{\circ}$ during spring/summer, and $45^{\circ}$

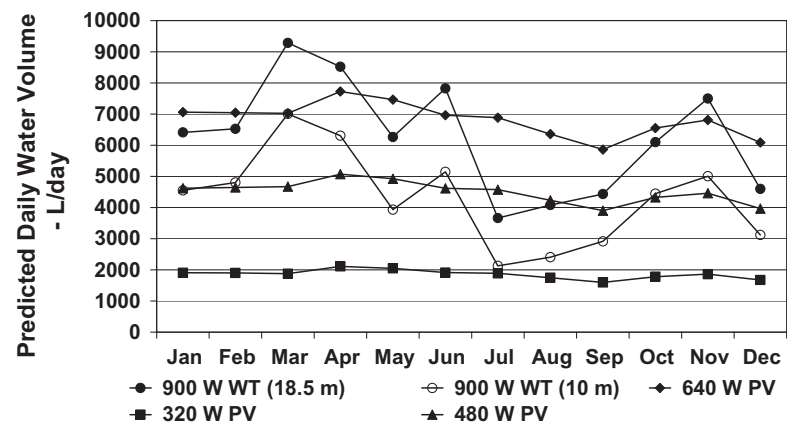

Fig. 8. Predicted daily water volume pumped by $900 \mathrm{~W}$ WT (10 and $18.5 \mathrm{~m}$ heights) and three solar PV arrays $(320,480$, and $640 \mathrm{~W})$ for a Grundfos 11SQF-2 pump (75 m head) in 2006 at Bushland, TX.

during fall/winter (latitude at Bushland, TX is $35.2^{\circ}$ ). Since the system should be sized for the highest water requirement (e.g. August), the $10 \mathrm{~m}$ height WT was similar to the $320 \mathrm{~W}$ PV array in meeting the water demand, and the $18.5 \mathrm{~m}$ height WT was similar to the $480 \mathrm{~W} \mathrm{PV}$ array. The $640 \mathrm{~W} \mathrm{PV}$ array would be able to supply water for the largest herd of beef cattle. Water pumped by the WT during the spring could potentially be saved for summer, but the cost of storage tanks or reservoirs are great. In addition, if open tanks are used, evaporation would reduce the amount of water that is stored. A better option is to use the additional wind or solar electricity in fall, winter, and spring for some other purpose. For example, during the winter the excess electricity could be used to power stock tank heaters. If hydrogen fuel cells become cost effective, extra pumped water could be converted to hydrogen and oxygen through electrolysis using excess renewable electricity, and the hydrogen could be used later for powering vehicles.

Daily water volumes of the hybrid WT/PV array systems can be estimated for 2006 by just adding the daily water volume of the WT to that of the three PV arrays (Fig. 9). These hybrid approximations assume the WT and PV arrays will not interfere with each other and that they will not be synergistic. Because the power from the PV arrays is fairly constant throughout the year, adding the WT to the PV array has the effect of increasing the daily water pumped during months when water demand is not highest. The pumping of excess water can be prevented by utilizing a float switch when the stock tank is full. Disconnecting the PV array from the pump is not a problem, but if the WT was disconnected from the pump, the WT rotor will spin faster causing more wear and tear on the WT and also increase the noise level (Vick and Clark, 2005). The power output, additional wear and tear, and noise emission of this WT can be eliminated by shorting the phases ${ }^{6}$ with a switch, but this will result in an increase in maintenance. The main disadvantage of a hybrid WT/

\footnotetext{
${ }^{6}$ Cannot short phases on all WT's - on some WT's shorting out the phases could result in damaging the generator.
} 


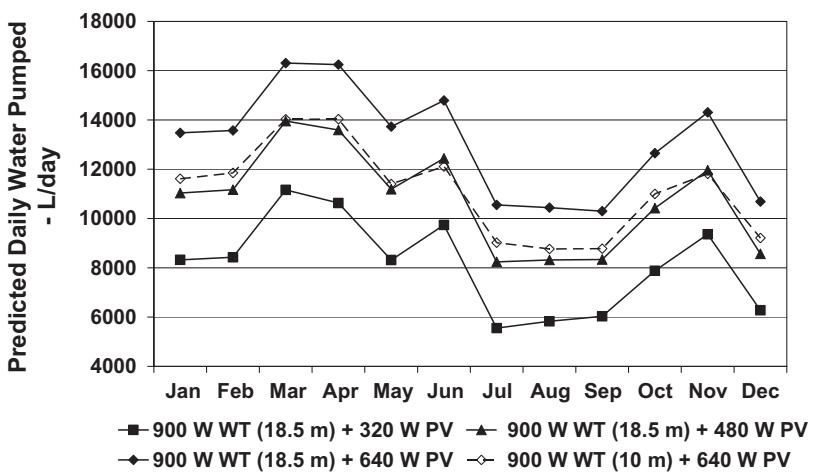

Fig. 9. Predicted daily water volume pumped by $900 \mathrm{~W}$ WT + PV array (320, 480, and $640 \mathrm{~W}$ ) for a Grundfos 11SQF-2 pump ( $75 \mathrm{~m}$ head) in 2006 at Bushland, TX. (Note: two different WT heights for WT $+640 \mathrm{~W}$ PV array.)

PV array compared to a PV array system alone is the additional cost of adding the WT unless the excess WT electricity generated was used for another purpose. However, an advantage of having the WT is to let it serve as a backup in case something happens to the PV array, so this will increase reliability. Also, if the hybrid WT/PV system pumps a much larger amount of water than what the WT and PV array could pump separately, the hybrid WT/PV array could be the least cost system even if excess electricity is not used for another application. The one hybrid case with the $10 \mathrm{~m}$ height WT shows the predicted amount of water that could be pumped if a rancher/farmer installed the WT on an existing windmill tower (e.g. saving the cost of purchasing and installing an $18.5 \mathrm{~m}$ WT tower).

The average flow rate and pump efficiency of the three hybrid systems tested were compared in Figs. 10 and 11. The flow rate curves in Fig. 10 are similar to the DC power curves in Fig. 5. The flow rate of all three hybrid systems are similar up to $600 \mathrm{~W} / \mathrm{m}^{2}$, but then the three diverge. The flow rate of the WT/640 W PV array was greatest, the WT/480 W PV array was next, and the WT/320 W PV array was least with the respective average peak flow rates being $32.5,28$, and $23 \mathrm{~L} / \mathrm{min}$. The average pump efficiencies (Fig. 11) are very similar to the flow rate curves in

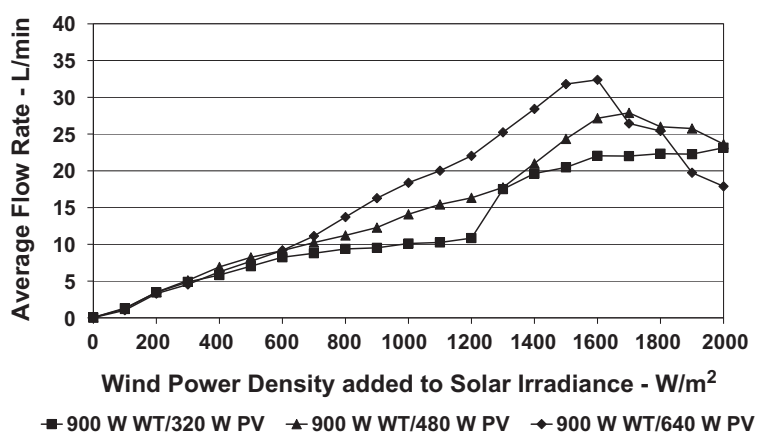

Fig. 10. Average measured flow rates of Grundfos 11SQF-2 pump $(75 \mathrm{~m}$ head) powered by three WT/PV array hybrids (solid symbols are mean value).

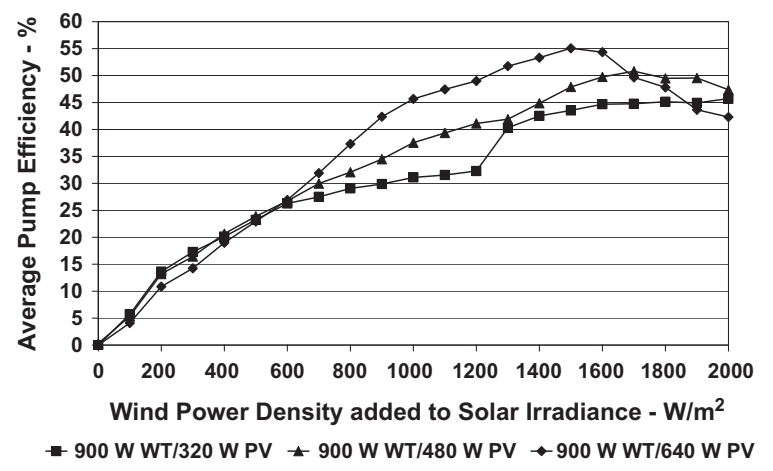

Fig. 11. Average pump efficiency of Grundfos $11 \mathrm{SQF}-2$ pump $(75 \mathrm{~m}$ head) powered by three WT/PV array hybrids.

Fig. 10 with the average peak pump efficiencies being $55 \%$, $51 \%$, and $46 \%$, respectively for WT/640 W PV array, WT/ $480 \mathrm{~W}$ PV array, and WT/320 W PV array. The greatest improvement in pump efficiency occurred when the WT was added to the $320 \mathrm{~W}$ PV array which increased the average peak pump efficiency of that PV array from $30 \%$ to $46 \%$. Adding the WT to the $480 \mathrm{~W}$ PV array and the $640 \mathrm{~W}$ PV array improved the average peak pump efficiency from $43 \%$ to $51 \%$ and $51 \%$ to $55 \%$, respectively.

Fig. 12 presents the predicted daily water pumped over 9 months (December 2010-August 2011) by the three hybrid systems tested, and by the WT and PV arrays individually (e.g. two wells and two helical pumps) and then added. This graph demonstrates when the WT and PV array are interfering with one another (e.g. open symbols higher) or whether the hybrid operates synergistically (e.g. solid symbols higher). For six of the 9 months the hybrid WT/320 W PV array pumped more water than if WT and PV array operated individually. For the month of August, the amount of water increased $1500 \mathrm{~L} /$ day $(28 \%)$ for this hybrid system compared to if the WT and PV array operated individually. For the hybrid WT/ $480 \mathrm{~W}$ PV array, 3 months were approximately the same as operating the WT and PV array individually, but the

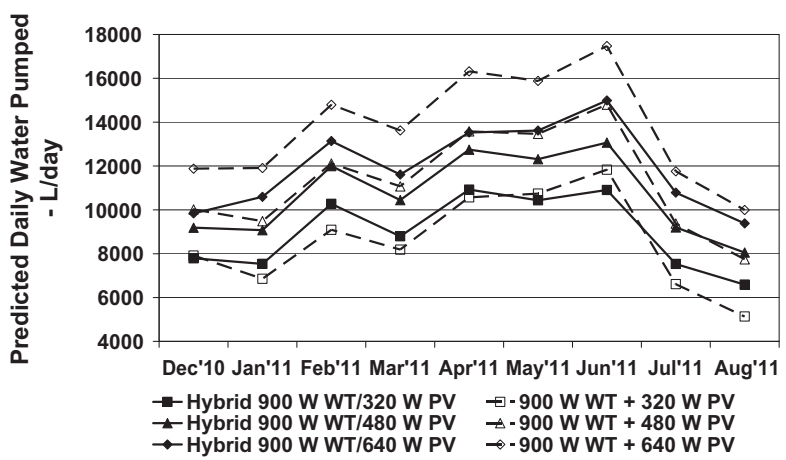

Fig. 12. Predicted daily water pumped by hybrid WT/PV systems and the addition of individual WT and PV arrays for a Grundfos 11SQF-2 pump (75 $\mathrm{m}$ head) at Bushland, TX. Solid symbols and lines represent hybrid WT/PV systems, and open symbols and dashed lines are addition of individual WT and PV arrays. 
other 6 months the hybrid would have pumped less water than by the WT and PV array individually. Finally, for the hybrid WT/640 W PV array, the hybrid pumped less water for all 9 months compared to what the WT and $640 \mathrm{~W}$ PV array could have pumped individually (500$2000 \mathrm{~L} /$ day less depending on the month).

\subsection{Analysis of DC voltage of wind turbine, $P V$ arrays, and hybrid WT/PV systems}

Two of the three hybrid off-grid WT/PV array systems pumped less water than if water was pumped by the WT and PV arrays individually. We suspect the interference between the higher Wattage PV arrays (480 and $640 \mathrm{~W}$ ) and the WT was caused by a voltage mismatch between the WT and PV array. The Grundfos control system uses an uncontrolled three phase rectifier that requires a $0.7 \mathrm{~V}$ higher voltage than the solar array voltage for the WT to contribute energy to the hybrid system. Fig. 13 presents the measured DC voltages of the WT and the different PV arrays when they are operated individually whereas Fig. 14 presents the measured DC voltages of the hybrid WT/PV arrays. The average standard deviation in voltage for the three hybrid WT/PV array systems were 12,17 , and $24 \mathrm{~V}$ from lowest PV array power rating to highest, respectively.

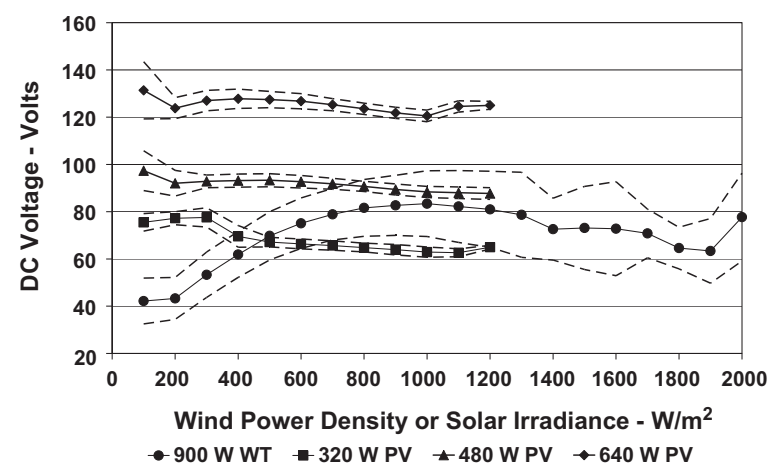

Fig. 13. Measured DC voltage of $900 \mathrm{~W}$ WT and three solar PV arrays $(320,480$, and $640 \mathrm{~W})$. Symbols are mean values and dashed lines represent $+/-1$ standard deviation.

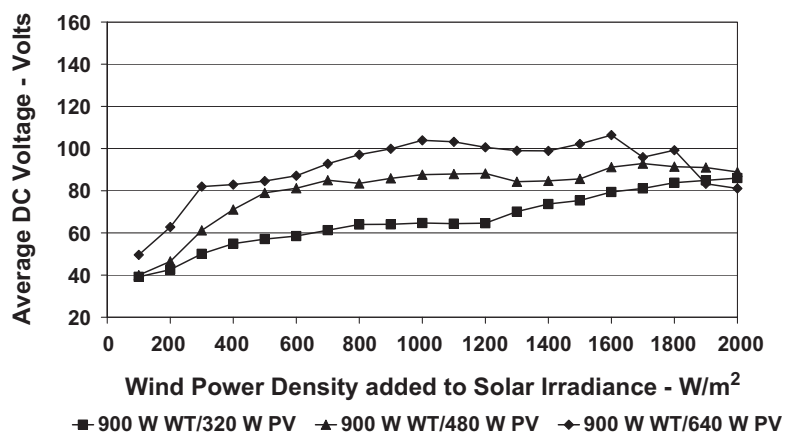

Fig. 14. Average DC voltage of three hybrid WT/PV array systems (symbols are mean values).
For the WT/320 W PV hybrid (e.g. the hybrid system that usually pumped more water than if WT and PV array were operated individually), the WT voltage curve crosses the PV array voltage curve at $500 \mathrm{~W} / \mathrm{m}^{2}$ and the maximum average voltage variation was about $20 \mathrm{~V}$ (Fig. 13). For the WT/320 W PV array hybrid, the WT increased from $40 \mathrm{~V}$ (at low solar irradiance and wind speed levels) to $80 \mathrm{~V}$ when the WT was furling (Fig. 14). At low wind speeds the WT voltage was not affected by the $320 \mathrm{~W}$ PV array, but at moderate wind speeds up to the furling wind speed the voltage was decreased by the addition of PV array (Figs. 13 and 14). At wind speeds beyond furl the PV array appeared to be increasing the voltage which improved the flow rate and the pump efficiency (Figs. 13 and 14). Another possibly important point was that the WT voltage was greater than that of the $320 \mathrm{~W}$ PV array most of the time (Fig. 13).

For the WT and $480 \mathrm{~W}$ PV array, at low wind speeds the PV array was $30-40 \mathrm{~V}$ higher than that of the WT, but as the wind speed approached the furling wind speed $\left(1600 \mathrm{~W} / \mathrm{m}^{2}\right)$, the PV array and WT voltages were almost the same (Fig. 13). However, in the windier months this hybrid system pumped less water than the WT and PV array could pump individually (Fig. 12) which appeared to contradict the hypothesis that matching the voltages will improve the hybrid pumping performance. The voltage of the $640 \mathrm{~W}$ PV array was always greater than that of the WT ranging from 40 to $80 \mathrm{~V}$ greater (Fig. 13), and the greatest interference occurred for this hybrid (Fig. 12) which did support the hypothesis that the hybrid could be improved if the WT voltage was closer to that of the PV array.

The average voltage of the hybrid WT/480 PV array was greater than the average voltage of the WT (Figs. 13 and 14), but this hybrid had more interference occur between the WT and PV array. The average voltage of the hybrid $\mathrm{WT} / 640 \mathrm{~W}$ PV array was $20 \mathrm{~V}$ greater than the WT by itself, but the average voltage of the PV array was decreased about 20-30 V for this hybrid (Figs. 13 and 14).

\subsection{Improving the off-grid water pumping performance of hybrid WT/PV array by controlling the voltage}

Skretas and Papadopoulos (2008) proposed improving the performance of an off-grid hybrid WT/PV water pumping system with buck (e.g. decrease voltage) and boost (e.g. increase voltage) converters. Other research teams have developed ways to control WT voltage using buck, boost, and buck/boost converters: Arifujjaman et al. (2006), Tafticht et al. (2006), Hu et al. (2008), Ni et al. (2009), and Qiang et al. (2011). Although each of these control/converter systems had their advantages for different applications, we decided that we will add a controller and a buck/boost converter arrangement to our existing hybrid WT/PV water pumping system which is similar to what Qiang et al.(2011) used since their experiment demonstrated a relatively constant voltage (only $3 \%$ ripple) even 


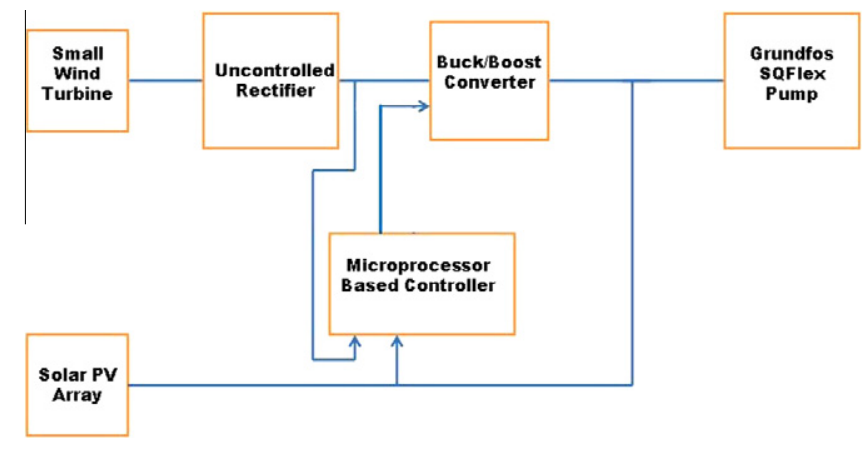

Fig. 15. Schematic of control loop for improving hybrid WT/PV array systems.

though the WT input DC voltage varied from 20 to $100 \mathrm{~V}$. A schematic of our proposed control loop is depicted in Fig. 15. The controller will monitor the rectified output voltage from the WT and the output voltage of the PV array. The controller will adjust the voltage from the WT and attempt to match the voltage from the PV array when the power from the PV array can be added to WT. During periods when the voltage from the PV array is below the useable range for the pump and there is sufficient voltage from the WT, the controller will adjust the voltage of the WT to operate the pump efficiently without power from the PV array. Likewise, when WT voltage is below the useable range, only PV array power will be used to power the pump.

\section{Conclusions}

Combining a WT with a solar PV array for an off-grid water pumping system was more of a challenge than connecting a hybrid WT/PV array to the utility grid. The offgrid system was more difficult because the voltage of the WT varied appreciably with wind speed and therefore did not match the voltage of the PV array which supplied approximately a constant voltage when operated alone. For on-grid hybrid WT/PV systems, this mismatching was not a problem because the WT's and PV arrays were connected to a utility grid through inverters which converted the $\mathrm{DC}$ or variable voltage 3-phase $\mathrm{AC}$ to constant voltage/frequency AC electricity used by the utility. However, on-grid systems have other problems that off-grid systems do not have which are: cost of the inverter, inverter efficiency loss, and required utility grid or the cost of utility grid extension.

For the hybrid off-grid $900 \mathrm{~W}$ WT/320 W PV array, during the highest water demand month of August, the daily water pumped increased by $1500 \mathrm{~L}$ or $28 \%$ more than if the WT and PV array were operated individually. However, for the hybrid off-grid $900 \mathrm{~W}$ WT/640 W PV array during the same month of August, the average daily water pumped decreased $600 \mathrm{~L}$ or was $6 \%$ less than if the WT and PV array were operated individually. Since the voltage mismatch between the WT and $640 \mathrm{~W}$ PV array was much greater than that between the WT and the $320 \mathrm{~W}$ PV array, we expect that correcting this voltage mismatch will improve the performance of the hybrid systems.

For the Southern Great Plains, if a WT was combined with a solar PV array for just water pumping, the water pumped in the summer would increase when the demand was greatest, but excess water would be pumped in the other seasons (e.g. fall, winter, and spring) unless the WT was braked (e.g. shorting phases of WT) electrically, but this will result in additional maintenance. If the WT was disconnected from the pump via an automatic float switch in the controller when the stock tank was full, the noise level would be greater and the greater blade rotor speed will add additional stress on the WT and decrease its lifetime. However, another option is to use the excess WT generated electricity for other purposes like heating water in the stock tank during winter, charging batteries, or producing hydrogen for powering fuel cell powered farm/ranch vehicles.

One of the objectives in this research was to determine which PV array size would be the most efficient with a $900 \mathrm{~W}$ WT. Since the average peak pump efficiency $(55 \%)$ was greatest for the $640 \mathrm{~W}$ PV array with the $900 \mathrm{~W}$ WT, that hybrid system appeared to be the most efficient of the systems tested for the Southern Great Plains.

Based on the large variation of the measured DC voltage from the uncontrolled rectifier of the hybrid WT/PV array water pumping systems, we have selected a controller/converter system which we believe will improve the hybrid WT/PV array performance, and we plan to conduct testing soon.

\section{References}

Akins, R., 1978. Performance Evaluation of Wind Energy Conversion Systems Using the Method of Bins-Current Status. Sandia Laboratories, Albuquerque, NM, SAND77-1375.

Arifujjaman, M., Iqbal, M., Quaicoe, J., 2006. Maximum power extraction from a small wind turbine emulator using a DC-DC converter controlled by a microcontroller. In: Proceedings of 4th International Conference on Electrical and Computer Engineering, December 19-21, 2006, pp. 213-216. <http://www.ieexplore.ieee.org >.

Baring-Gould, I., 1998. Hybrid2: The Hybrid System Simulation Model Version 1.1. Users Manual. NREL/TP-440-21272. DE96007901, 63p. $<\mathrm{http}$ ://www.umass.edu/windenergy/research.topics.tools.software. hybrid2.php $>$.

BP Solar, 2003. BP 3160: 160 Watt Photovoltaic Module. <http:// www.bpsolar.us/sites/default/files/product_data_sheet_bp_3160b_03_ 4022_1_en.pdf>.

Clark, R., Vick, B., 2008. Livestock water pumping with wind and solar power. In: American Society of Agricultural and Biological Engineers International Meeting, Paper \#084176, June 29-July 2, Providence, RI, 14p. <http://www.cprl.ars.usda.gov>.

Foster, R., 2009. Solar Energy: Renewable Energy and the Environment. CRC Press, Publisher, 382p.

Gipe, P., 2004. Wind Power: Renewable Energy for Home, Farm, and Business. Chelsea Green Publishing Co., 496p.

Hicks, R., Owens, F., Gill, D., Martin, J., Strasia, C., 1988. Water intake by feedlot steers, Okla. Anim. Sci. Res. Rpt. Mp-125, 208 212.

Hu, B., Chang, L., Xue, Y., 2008. Research on a novel buck-boost converter for wind turbine systems. In: Proceedings of International 
Conference on Sustainable Energy Technologies, November 24-28, pp. 228-233. <http://www.ieexplore.ieee.org $>$.

Kamel, K., Dahl, C., 2005. The economics of hybrid power systems for sustainable desert agriculture in Egypt. Energy 30, 1271-1281.

Lilienthal, P., 2005. The HOMER Micropower Optimization Model. NREL/CP-710-37606. <http://www.homerenergy.com/>.

Marion, W., Wilcox, S., 1994. Solar Radiation Data Manual for FlatPlate and Concentrating Collectors. April 1994, NREL/TP-463-5607, DE93018229, 252p. <http://www.nrel.gov/docs/legosti/old/5607.pdf>.

Neal, B., Clark, R., 2007. Speed control of a small wind turbine using electrical loading. In: American Wind Energy Association Windpower Conference. Los Angeles, CA, 12p. <http://www.cprl.ars.usda.gov>.

Nelson, V., 2009. Wind Energy: Renewable Energy and the Environment CRC Press, Publisher, 304p.

Nelson, V., Clark, R., Foster, R., 2004. Wind Water Pumping. West Texas A\&M University - Alternative Energy Institute, 108p.

Ni, L., Patterson, D., Hudgins, J., 2009. Maximum power extraction from a small wind turbine using 4-phase interleaved boost converter. In: Proceedings of Power Electronics and Machines in Wind Applications, June 24-26, 2009, 5p. <http://www.ieeexplore.ieee.org $>$.

Odeh, I., Yohanis, Y., Norton, B., 2006. Influence of pumping head, insolation and PV array size on PV water pumping system performance. Sol. Energy 80, 51-64.

Osterwald, C., Anderberg, A., Rummel, S., Ottoson, L., 2002. Degradation analysis of weathered crystalline-silicon PV modules, NREL/CP520-31455, 4p.

Qiang, G., Silei, S., Junjie, W., 2011. A control circuit architecture based on SEPIC topology for off-grid wind power generation. In: Proceedings of International Conference on Electronics, Communications and Control, September 9-11, pp. 9-12. <http://www.ieeexplore.org $>$.

Skretas, S., Papadopoulos, D., 2008. Systematic procedure for efficient design of electric water pumping systems fed by PV or/and WECS: application using measured meteorological data for the city of Xanthi/ Thrace, Greece. Energy Convers. Manage. 49, 596-607.

Tafticht, T., Agbossou, K., Cheriti, A., 2006. DC bus control of variable speed wind turbine using a buck-boost converter. In: Proceedings of Power Engineering Society General Meeting, October, 2006, 5p. $<\mathrm{http}: / /$ www.ieeexplore.ieee.org $>$.

Vick, B., Clark, R., 1997. Performance and economic comparison of a mechanical windmill to a wind-electric water pumping system. In: American Society of Agricultural Engineers Conference. Paper No. 974003, 12p. <http://www.cprl.ars.usda.gov>.

Vick, B., Clark, R., 2005. Performance and acoustic analysis of a small wind turbine used with a helical pump for livestock watering. In: American Wind Energy Association Windpower Conference, 11p. $<$ http://www.cprl.ars.usda.gov $>$.

Vick, B., Clark, R., 2009. Determining the optimum solar water pumping system for domestic use, livestock watering, or irrigation. In: American Solar Energy Society Solar Conference, 8p. <http://www.cprl.ars. usda.gov>.

Vick, B., Clark, R., 2011. Experimental investigation of solar powered diaphragm and helical pumps. Sol. Energy 85, 945-954.

Vick, B., Clark, R., Ling, S., 1999. One and a half years of field testing a wind-electric system for watering cattle in the Texas Panhandle. In: American Wind Energy Association Windpower Conference, 10p. $<$ http://www.cprl.ars.usda.gov $>$.

WTAMU-AEI, 2011. <http://www.windenergy.org $>$.

Yang, H., Lu, L., Zhou, W., 2007. A novel optimization sizing model for hybrid solar-wind power generation system. Sol. Energy 81, 76-84.

Zhou, W., Yang, H., Fang, Z., 2008. Battery behavior prediction and battery working states analysis of a hybrid solar-wind power generation system. Renew. Energy 33-6, 1413-1423.

Zhou, W., Lou, Chengzhi, Li, Zhongshi, Lu, Lin, Yang, Hongxing, 2010. Current status of research on optimum sizing of stand-alone hybrid solar-wind power generation systems. Appl. Energy 87, 380-389. 